\title{
Modelling RMB Internationalization and Impact on Capital Flow
}

\author{
M.M. Li ${ }^{\text {a }}$, F.M. Qin ${ }^{\mathrm{a}}$ and Z.Y. Zhang \\ ${ }^{a}$ School of Economics, Shandong University, China \\ ${ }^{b}$ School of Business \& Law, Edith Cowan University, Australia \\ Email: zhaoyong.zhang@ecu.edu.au (Zhang)
}

\begin{abstract}
China began its economic reforms in the end of the 1970s, which have successfully transformed the country into an important trading nation and manufacturing centre in the world over the past three decades. Despite China's recent economic slowdown, the IMF forecasts that China will continue to be the largest contributor to global GDP growth. In addition, the rate of return for holding RMB over the past ten years has been one of the highest, which explains the strong portfolio capital inflows since 2004. Probably the only remaining issue is about China's capital control, especially over the flows of portfolio investment. The progress of RMB internationalization helps facilitate the short term capital flows, and is believed to have a new interactive effects on the exchange rate expectation and capital flows nexus.
\end{abstract}

This paper intends to employ the asset portfolio balance model to explore the effect of RMB exchange rate expectation on RMB internationalization. In particular, we empirically explore the relationship between RMB exchange rate expectation, RMB internationalization and short-term capital flow by using SVAR model and the monthly data from February 2004 to November 2014. The results indicates that RMB exchange rate appreciation could increase the demand of foreign investors for RMB and RMB denominated bonds and vice versa, and also attract short-term capital inflow through reducing the capital flow cost. This paper implies that, associated with the rapid RMB internationalization, the central bank needs to pay more attention to the short term capital flow as its destabilizing effect may cause panic to the financial system.

\section{JEL Classification: $\quad$ G28, F21}

Keywords: $\quad R M B$ exchange rate expectation, $R M B$ internationalization, short-term capital flow, interactive mechanism 


\section{INTRODUCTION}

The global financial crisis (GFC) in 2008 has revealed the flaw of existing international monetary system and created a greater awareness worldwide of the importance to establishing both a more resilient domestic economic and financial system and a better functioning global financial system. Since the GFC, the Chinese government has adopted several measures to reform its exchange rate system and promote the RMB internationalization process. It has been documented that there are three major determinants for internationalizing a currency, i.e. the economic size of the country in terms of output or trade; the rate of return proxied by the domestic inflation or exchange rate; and the depth of financial markets in term of foreign exchange market turnover. It is an interesting question to ask whether or not China has fulfilled these criteria.

China began its economic reforms in the end of the 1970s, which have successfully transformed the country into an important trading nation and manufacturing centre in the world over the past three decades. With its nearly double-digit growth rates for more than three decades from 1979 to 2014, China is now the world's second largest economy and largest economy in merchandise trade and foreign exchange reserves. Despite China's recent economic slowdown, the IMF forecasts that China will continue to be the largest contributor to global GDP growth. In addition, the rate of return for holding RMB over the past ten years has been one of the highest, which explains the strong portfolio capital inflows since 2004. Moreover, the domestic inflation rate has been well managed (Prasad and Wei, 2010). Probably the only remaining issue is about China's capital control, especially over the flows of portfolio investment. However, it is still debatable whether full capital account convertibility is a prerequisite for achieving an international currency status when one reviews the internationalization process of the US dollar. As a matter of fact, when the IMF announced the inclusion of RMB into its Special Drawing Rights (SDR) reserve currency basket effective since October 2016, it officially recognizes that the RMB has met the criterion of being "freely usable", reflecting China's expanding role in global trade and the substantial increase in the international use and trading of the renminbi. This lends support to the view that full capital account liberalization is not a necessary condition for an international currency. Nevertheless, given China's increasing importance as an economic power and major trading nation, the Chinese authorizes have recently reaffirmed their determination to gradually liberalize its financial sector and move towards full capital account convertibility.

In recent years, the Chinese government has implemented measures for encouraging the use of the RMB in cross-border transactions and the creation of an RMB offshore market in Hong Kong, Singapore and other international financial centres to push the internationalization of the Chinese RMB. The recent initiatives to liberalize the capital account and push RMB internationalization include the "Shanghai-Hong Kong Stock Connect" and "Shenzhen-Hong Kong Stock Connect". According to the Bank of International Settlements, the RMB was the 8th most actively traded currency in the 2016 triennial survey of foreign exchange turnover (BIS, 2016), and became the second most used currency in traditional trade finance and the number 5th payments currency of the world (PBOC, 2015). The rising significance of the RMB is viewed as a natural response to the growing weight of China's trade and investment flows in the world economy and also a result of its rapid economic and financial integration with the rest of the world.

Along with RMB exchange rate system reform and internationalization of the currency, another issue is about the short term capital flows. Several existing studies have examined the factors that affect international short term capital flows from different perspective such as interest rate spreads between home and abroad, exchange rate and its expectation, and assets price (Prasad and Wei, 2005; Bouvatier, 2010; Fang, 2012). Since 2005 when China switched its exchange rate system from the dollar-peg to a basket of currencies, the RMB has appreciated in nominal terms by over 34 per cent against the US dollar and by 42 per cent on a real (inflation-adjusted) basis between 2005 and 2013. Due to a strong market expectation of RMB, there were more short term capital inflows to China in recent years. However, this expectation has changed to RMB depreciation from the beginning of 2014, which has led to the short term capital outflow since then.

Although exchange rate expectation is an important fact affecting the short term capital flows, the relationship between exchange rate expectation and short term capital flows is no longer a straightforward one when we incorporate RMB internationalization into our analysis. The progress of RMB internationalization helps facilitate the short term capital flows, and is believed to have a new interactive effects on the exchange rate expectation and capital flows nexus. The purpose of this study is to assess from a 
portfolio approach perspective the effect of exchange rate expectation on Chinese RMB internationalization, and empirically test the interactive effects among short-term capital flows, RMB appreciation expectation and internationalization process. Our results show that RMB exchange rate appreciation could lead to an increase in the foreign demand for RMB and RMB denominated assets, while RMB internationalization would help attract more short-term capital inflow due to the reduced transaction costs. This study and the findings have important policy implications for the process of RMB internationalization and short-term capital flows, especially regarding how to manage the destabilizing effect of the short-term capital flows.

The remainder of this paper is organized as follows. Section 2 discuss the theoretical framework and the models used in this study. In section 3 we discuss the data and the empirical results from our models. Section 4 concludes with some policy implications.

\section{THEORETICAL FRAMEWORK}

By definition, the RMB internationalization refers to the process of taking the RMB outside of China as an international currency and allowing nonresidents to hold and use the RMB extensively overseas as a major pricing and settlement currency for trade, investments and reserves. In particular, in this study we simplify the RMB internationalization process by focusing on the analysis of the foreign demand for RMB and substitution effect of other currencies for the RMB. The foreign demand for the RMB can be divided into two components, one is for the cross border trade settlement and outward direct investment in RMB, and another is for the speculative purpose by the foreign investors for the RMB denominated assets (Jiang et. al., 2012).

We adopt the assets portfolio balance model to explore the effect of the expected change of RMB exchange rate on RMB internationalization and then how the latter affect the short term capital flows. The assets portfolio balance model was proposed by McKinnon and Oates (1966), Girton and Henderson (1976) and Branson (1980), and developed by Girton and Roper (1981), Cuddingto (1983) and Zervoyianni (1993) to include currency substitution between foreign and domestic assets in the model. When the rate of asset return changes, the domestic investors will adjust their portfolio through substituting domestic assets for foreign exchange or foreign bonds, which will affect the demand for currencies. Based on the assets portfolio model a la Cuddington (1983) and Adebiyi (2005), we set up a foreign demand model for RMB with the following assumptions:

- the foreign investors pursue to maximize their return from holding the RMB at a given level of risk;

- out of their total wealth, the foreign investors hold four different types of assets consisting of domestic assets, local bonds, foreign exchange (RMB) or RMB denominated assets; and

- investors can freely convert from one to another asset by changing the relative composition of the portfolios.

In this assets portfolio balance model, the foreign demand for assets is determined by the relative rate of return of the assets, income and total wealth. We then specify the foreign demand function for the RMB as follows:

$$
M^{d}=a+a_{1} r+a_{2} e r+a_{3}\left(e r+r^{*}\right)+a_{4} Y+a_{5} W
$$

Where $M^{d}$ denotes the logarithm of foreign nominal demand for RMB, $r$ is the yield for local bonds, er is the rate of expected RMB appreciation, $r *$ refers to the interest rate for RMB denominated bonds, $Y$ refers to the logarithm of nominal income in the foreign country and $W$ is the total wealth of the foreign investors. In this model, we set the foreign nominal monetary income as 0 . When $r$ rises, the foreign investors increase their demand for foreign bonds and reduce their demand for RMB and RMB denominated asset. As a result, the coefficient of $r, \mathrm{a}_{1}<0$; when $e r$ increases, the local price of RMB in the foreign country is expected to rise, which leads to an increase in demand for RMB by local investors. Therefore, the coefficient of er, $\mathrm{a}_{2}>$ 0 . When $e r+r^{*}$ increases, the demand for RMB denominated bonds increases and decrease demand of RMB, thus, the coefficient of $e r+r^{*} \mathrm{a}_{3}>0$. RMB demand function also depends on foreign income $Y$ and the total wealth $W$, their coefficients are a $4>0$, a $5>0$, respectively. 
With a similar fashion, we specify the demand function for RMB denominated bonds as follows:

$$
B^{d}=B^{d}\left(\stackrel{-}{r}, \stackrel{+}{e r}, e r+r^{*}, \bar{Y}, \stackrel{+}{W}\right)
$$

When both $r$ and $e r$ decrease and $\left(e r+r^{*}\right)$ increases, foreign demand for RMB denominated bonds increase. Both equation (1) and equation (2) suggest that RMB appreciation expectation will lead to an increase in foreign demand for the RMB and the RMB denominated bonds. However, one may note that the expected change of exchange rate affect the foreign demand for RMB bonds through two channels, both directly and indirectly. When er increases, it will raise the foreign demand for the RMB and decrease the demand for RMB bonds. However, the rise of er also affect the demand for RMB denominated bonds indirectly through the increase in $\left(e r+r^{*}\right)$ following the rise of $e r$, which then leads to an increase in demand for RMB bonds and lower demand for the RMB. In sum, when RMB appreciation expectation increases, foreign investors will raise their demand for the RMB and RMB denominated bonds.

$$
\begin{gathered}
\frac{\partial M^{d}}{\partial e r}=\frac{\partial M^{d}}{\partial r^{*}} \frac{\partial\left(e r+r^{*}\right)}{\partial e r}+\frac{\partial M^{d}}{\partial e r}>0 \\
\frac{\partial B^{d}}{\partial e r}=\frac{\partial B^{d}}{\partial r^{*}} \frac{\partial\left(e r+r^{*}\right)}{\partial e r}+\frac{\partial B^{d}}{\partial e r}>0
\end{gathered}
$$

Now we turn to the impacts of RMB internationalization on RMB exchange rate expectation. As aforementioned, the process of RMB internationalization implies that the RMB is to be used worldwide by non-residents for payment and investment, suggesting the foreign demand for RMB will increase, which will appreciate the RMB and leads to an increase in RMB appreciation expectation. On the other hand, currency internationalization could be driven by market or government (Cohen, 1971). When RMB internationalization is viewed as government driven, investors may not have the full confidence about the $\mathrm{RMB}$, which may lead to RMB depreciation expectation. Therefore, the effect of RMB internationalization on $\mathrm{RMB}$ exchange rate expectation is undetermined based on the above synthesize analysis.

In order to study the dynamic relationship of RMB exchange rate expectation, RMB internationalization and short-term capital flow, we specify the structural VAR model as follows:

$$
Y_{t}=A_{0}^{-1} c+A_{0}^{-1} \Gamma_{1} Y_{t-1}+A_{0}^{-1} \Gamma_{2} Y_{t-2}+\ldots+A_{0}^{-1} \Gamma_{p} Y_{t-p}+A_{0}^{-1} \mu_{t}
$$

$A_{0}=\left[\begin{array}{ccc}1 & -a_{12} & -a_{13} \\ -a_{21} & 1 & -a_{23} \\ -a_{31} & -a_{32} & 1\end{array}\right], \quad \Gamma_{t}=\left[\begin{array}{ccc}\gamma_{11}^{(i)} & \gamma_{12}^{(i)} & \gamma_{13}^{(i)} \\ \gamma_{21}^{(i)} & \gamma_{22}^{(i)} & \gamma_{23}^{(i)} \\ \gamma_{31}^{(i)} & \gamma_{32}^{(i)} & \gamma_{33}^{(i)}\end{array}\right], \quad Y_{t-i}=\left[\begin{array}{c}\text { Expect }_{t-i} \\ \text { InCurrency } \\ \text { Shortcapital }_{t-i}\end{array}\right] \quad c=\left[\begin{array}{c}c_{1} \\ c_{2} \\ c_{3}\end{array}\right], \quad u_{t}=\left[\begin{array}{c}u_{1 t} \\ u_{2 t} \\ u_{3 t}\end{array}\right], i=1,2, \ldots, p$

Where Expect denotes the RMB exchange rate expectation; InCurrency is the natural logarithms of RMB deposits on the Hong Kong offshore market; Shortcapital is short-term capital flow. $a_{k j}(k, j=1,2,3 ; k \neq j)$ in Matrix $A_{0}$ captures the correlation of the three variables in the same period.

\section{DATA DESCRIPTION AND EMPIRICAL RESULTS}

We use monthly series of data spanning from February 2004 to December 2014 in this study. There are three methods to calculate short-term capital flow: direct, indirect way and mixed methods. In this study we adopt the indirect way to estimate the short-term capital flows, the short-term capital flow is proxied by the increases in foreign exchange reserve minus export surplus and foreign direct investment. The data is collected from CEInet Statistics Database. For the robustness tests, we take the direct approach to proxy the short-term capital flows.

Exchange rate expectation can be proxied by the forward margin. In this study we use the RMB nondeliverable forward exchange rate (NDF) to calculate the forward margin as follows, 


$$
\text { Expect }=\frac{\text { one year } N D F \text { exchange rate of } R M B \text { against } U S D}{\text { spot exchange rate of } R M B \text { against } U S D}-1
$$

If Expect is larger than zero, it means that offshore market investors have appreciation expectation for RMB. Daily data for one year NDF exchange rate of USD against RMB is from Wind Database. One year NDF monthly data is obtained by simple averaging of one year NDF daily data. Spot exchange rate of USD against RMB comes from IFS. We convert the two rates into price of RMB denominated in US dollars.

There are several measures for the RMB internationalization. Although RMB settlement of cross-border trade and Standard Chartered RMB global indicator RGI can meet the need of the empirical study, the time span is too short and only available for the recent years. We decide to take the method from Sha and Liu (2014) and use the RMB offshore market deposits as the proxy for the RMB internationalization. Although there are several major RMB offshore markets including Hong Kong, London, Seoul, Frankfurt and Singapore, the Hong Kong market plays a dominant role and accounts for about $80 \%$ of the global RMB deposit business (Zhang and Qin, 2014). Thus, it is reasonable to select the Hong Kong RMB offshore market deposits as the proxy. We collect the monthly RMB deposits data from the Monthly Statistical Bulletin of Hong Kong Monetary Authority. In order to avoid the possible heteroscedasticity problems, we takes natural logarithms for Hong Kong offshore market RMB deposits.

We have conducted the ADF tests to check the time-series properties of the endogenous variables and the results of unit-root test are reported in Table 1 . The results shows that all the three variables are stationary in level though with different significance levels.

Table 1. ADF test results for variables

\begin{tabular}{c|c|c|c|c|c}
\hline Variable & $\begin{array}{c}\text { Test type } \\
(\mathrm{c}, \mathrm{t}, \mathrm{n})\end{array}$ & ADF statistic & Critical value & $\begin{array}{c}\text { Significance } \\
\text { level }\end{array}$ & Conclusion \\
\hline Shortapital & $(\mathrm{c}, 0,2)$ & -3.482 & -3.722 & $1 \%$ & Stationary \\
\hline lnCurrency & $(\mathrm{c}, \mathrm{t}, 4)$ & -3.148 & -3.251 & $10 \%$ & Stationary \\
\hline Expect & $(\mathrm{c}, \mathrm{t}, 3)$ & -4.031 & -4.032 & $1 \%$ & Stationary \\
\hline
\end{tabular}

Notes: $\mathrm{c}$ in Test type $(\mathrm{c}, \mathrm{t}, \mathrm{n})$ means containing intercept term. $\mathrm{t}$ means containing trend term. $\mathrm{n}$ is the lag order of the variables

Figure 1 presents the impulse response of the short-term capital flow to the shocks of RMB exchange rate expectation and RMB internationalization. The left Figure shows that the short-term capital flows respond positively to the shock of RMB exchange rate expectation. The positive response value reaches a maximum of 0.08902 in the first period and then gradually decreases. The results indicate that RMB appreciation expectation drives short-term capital inflow. The right Figure indicates that short-term capital flow has a positive response to one structural standard deviation shock of RMB internationalization. The positive response reaches a maximum of 0.0443 in the first period and then gradually decreases. In the fourth period, the response is nearly zero. The results indicate that RMB internationalization process could lead to an
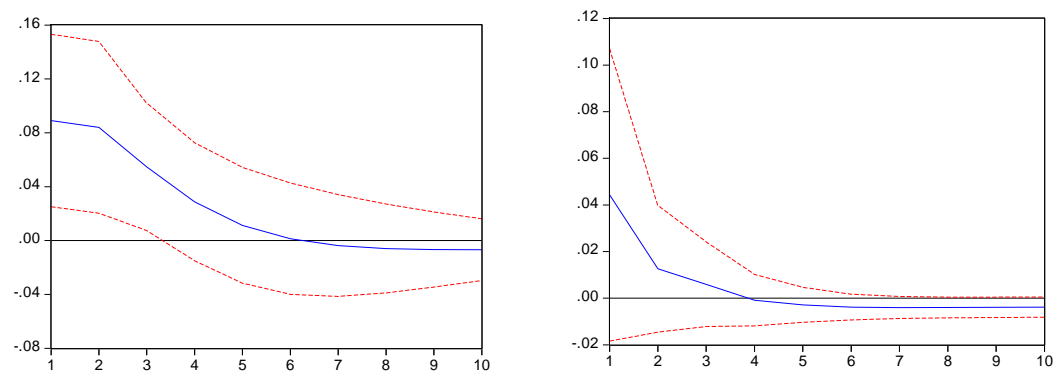

Figure1 Impulse Response Function of Shortcapital to Expcet and lnCurrency increase in the short-term capital inflow.

The impulse response function of RMB exchange rate expectation to $\mathrm{RMB}$ internationalization and short-term capital flow shocks shows that RMB exchange rate expectation has a negative response to the shock of offshore market RMB deposits (the results are available upon request). The negative response gradually increases and reaches a minimum of 0.000981 in the tenth period. These results indicate that the increase of offshore market RMB deposits could lead to RMB depreciation expectation. The possible reason is that increase of RMB internationalization is to a greater extent driven by government which may not be based on the economic and financial fundamentals. Thus, investors may lack confidence in RMB, and interpret the RMB internationalization process as political activities, a result of which would be the RMB depreciation. On the other hand, the RMB exchange rate expectation responds positively to one standard deviation shock of short-term capital flows. The response 
value reaches a maximum of 0.000489 in the second period and gradually decreases. The results show that short-term capital inflow could lead to RMB appreciation expectation in the short period.

The response of RMB internationalization to RMB exchange rate expectation shock is positive in the first period and gradually increases (results are available upon request). The response reaches a maximum of 0.087679 in the tenth period. The results suggest that RMB appreciation expectation has a significant positive effect on RMB internationalization. On the other hand, given a positive shock of short-term capital flow, offshore market RMB deposit responds positively and reaches a maximum of 0.018488 in the fourth period before slightly decreasing. Thus, short-term capital inflow could promote RMB internationalization and the positive response persists.

The results for variance decomposition for RMB internationalization, exchange rate expectation and shortterm capital flow are reported in Table 2 . It can be seen that $12.26 \%$ of short-term capital flow variance change can be explained by RMB exchange rate expectation. RMB exchange rate expectation leads to $54.72 \%$ of RMB internationalization change. The results suggest that effect of RMB exchange rate expectation shock on short-term capital flow and RMB internationalization dominates. It is also noted from Table 2 that RMB internationalization accounts for $1.44 \%$ of the short-term capital flow volatility and $1.39 \%$ of the change in RMB exchange rate expectation, respectively. The results suggest that the effects of RMB internationalization on the rest of the endogenous variables are still limited.

Table 2. Variance decomposition of three variables (in percentage)

\begin{tabular}{|c|c|c|c|c|c|c|}
\hline \multirow[b]{2}{*}{ Period } & \multicolumn{2}{|c|}{ lnCurrency } & \multicolumn{2}{|c|}{ Shortcapital } & \multicolumn{2}{|c|}{ Expcet } \\
\hline & Expect & Shortcapital & Expect & lnCurrency & lnCurrency & Shortcapital \\
\hline 1 & 13.73210 & 0.000000 & 5.865567 & 1.454348 & 0.000000 & 0.000000 \\
\hline 2 & 26.02769 & 1.859972 & 10.16790 & 1.440875 & 0.025708 & 0.149292 \\
\hline 3 & 34.92726 & 2.516458 & 11.67206 & 1.401610 & 0.108623 & 0.097211 \\
\hline 4 & 40.98235 & 2.802359 & 12.12022 & 1.392213 & 0.228724 & 0.113767 \\
\hline 5 & 45.19287 & 2.862174 & 12.18645 & 1.395828 & 0.379304 & 0.181998 \\
\hline 6 & 48.21681 & 2.838239 & 12.18613 & 1.405188 & 0.552765 & 0.266338 \\
\hline 7 & 50.47170 & 2.782980 & 12.19281 & 1.415315 & 0.744152 & 0.350070 \\
\hline 8 & 52.21166 & 2.720481 & 12.21155 & 1.425167 & 0.949340 & 0.424952 \\
\hline 9 & 53.59486 & 2.659767 & 12.23580 & 1.434492 & 1.164969 & 0.489254 \\
\hline 10 & 54.72182 & 2.604065 & 12.26082 & 1.443394 & 1.388098 & 0.543617 \\
\hline
\end{tabular}

\section{CONCLUSION}

In this paper we employ an asset portfolio model to assess the effect of exchange rate expectation on Chinese RMB internationalization, and empirically test the interactive effects among short-term capital flows, RMB appreciation expectation and internationalization process. Our results suggest that RMB exchange rate appreciation could lead to an increase in the foreign demand for RMB and RMB denominated assets, while RMB internationalization would attract more short-term capital inflow due to the reduced transaction costs. The empirical evidence from the SVAR model estimation confirms the results that expected RMB appreciation induce short-term capital inflow and promote RMB internationalization. However, the effect of RMB internationalization process on short-term capital flow and RMB appreciation expectation is found insignificant. The robustness checks confirm the evidence. The results have important policy implication for RMB internationalization and for maintaining a sound and stable financial system.

\section{REFERENCES}

Adebiyi, A.M. (2005). Broad Money Demand, Financial Liberalization and Currency Substitution. in Nigeria. Capital Markets Conference, Indian Institute of Capital Markets Paper.

Bouvatier, V. (2010). Hot Money Inflows and Monetary Stability in China: How the People's Bank of China Took Up the Challenge. Applied Economics, (12): 1533-1548. 
Li et al., Modelling RMB Internationalization and Impact on Capital Flow

Branson, W. H. (1980). Asset Markets and Relative Prices in Exchange Rate Determination. International Finance Section, Department of Economics, Princeton University.

Bank for International Settlements. 2016. Triennial Central Bank Survey of Foreign Exchange and Derivatives Market Activity. Basel.

Cohen, B.J. (1971). The Future of Sterling as an International Currency. London: Macmillan.

Cohen, B.J. (2012). The Yuan Tomorrow? Evaluating China's Currency Internationalization Strategy. New Political Economy, (3):361-371.

Cuddington, J.T. (1983). Currency Substitution, Capital Mobility and Money Demand. Journal of International Money and Finance, (2): 111-133.

Fang, X,M., Pei, P., and Zhang Y, H, (2012). Motivation and Effects of International Speculative Capital Inflow: Empirical Tests Based on Sample Data from 1999 to 2011. Journal of Financial Research, (1):65-77.

Jiang, X, L., Liu, W., and Ye Bingnan. (2012). The Effect of Exchange Rate Expectation on Offshore Market RMB Demand. Study of International Finance, (10):68-75.

Lardy, M., and Douglass, P. (2011). Capital Account Liberalization and the Role of the Renminbi. Peterson Institute for International Economics, Working Paper.

McKinnon, R.I., and Oates,W. (1966). The Implications of International Economic Integration for Monetary, Fiscal and Exchange Rate Policies. Princeton Studies in International Finance No. 16.

Prasad, E., and Wei, S. (2005). The Chinese Approach to Capital Inflows: Patterns and Possible Explanations. NBER Working Paper No.11306.

Sha, W, B., and Liu, H, X. (2014): "RMB Internationalization, Exchange Rate Volatility and Exchange Rate Expectation," Study of International Finance, (8):10-18.

Girton, L., and Henderson, D.W. (1976). Central Bank Operations in Foreign and Domestic Assets under Fixed and Flexible Exchange Rates. Board of Governors of the Federal Reserve System.

Girton, L., and Roper, D. (1981). Theory and Implications of Currency Substitution. Journal of Money, Credit and Banking, (1): 12-30.

Zervoyianni, A. (1993). International Macroeconomic Interdependence, Currency Substitution, and Price Stickiness. Journal of Macroeconomics, (1): 59-86. 